
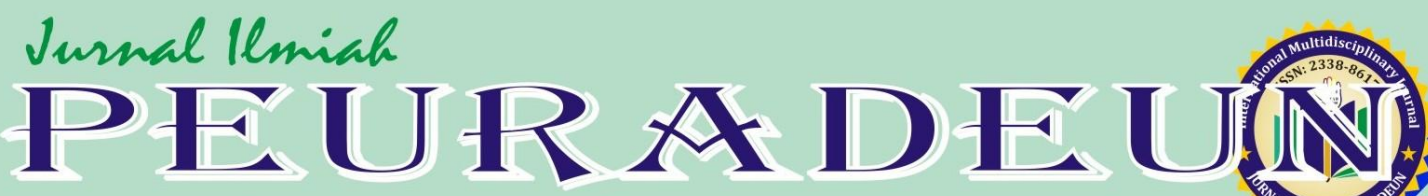

Media Kajian Ilniah Sosial, Politik, Hukum, Agana dan Budaya

THE ROLE OF CROSS-CULTURAL COMMUNICATION COMPETENCE: EFFECTIYE TK . SFORMATIONAL LEADERSHIP ACROSS CULTURES Elena Lvina -

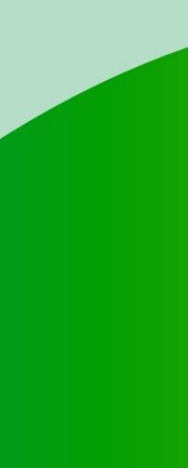

EARIXIEM

INIST CONSCIOUSNESS SS AND IDEA AMONG MUSLIM
WOMEN IN 1920s INDONESIA Farid Muttaqin

RELIGION, CHURCH, INTIMATE CITIZENSHIP AND GENDER EQUALITY (An Analysis of Differences in Gender Equality Policies in European Catholic Countries) Mieke Verloo

EPISTEMOLOGI ISLAM DAN REFORMASI WAWASAN PENDIDIKAN Kamrani Buseri

DIRECTION OF MORAL EDUCATION TEACHER TO ENRICH CHARACTER EDUCATION Mohd Zailani Mohd Yusoff \& Aswati Hamzah ART AND ENTERTAINMENT IN ISLAM Misri A. Muchsin

\section{JIP}

International Multidisciplinary Journal OAJI: 745/1396982282-2014/R-6.465 ORCHID iDs: 0000-0001-8492-315X
Thomson Reuters: RID-F-6135-2014 ISI Impact Factor Value 2014 ICR: 0.479 Copernicus ICV 2013: 4.05 Google Scholar Index-h:3, i10: 3

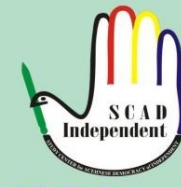

SCAD Independent IAO Accreditation 4-8362/387/IAO/2014 


\title{
DIRECTION OF MORAL EDUCATION TEACHER TO ENRICH CHARACTER EDUCATION
}

\author{
Mohd Zailani Mohd Yusoff ${ }^{1}$ \\ Aswati Hamzah²
}

\begin{abstract}
This paper discusses moral education which should begin by focussing on what exactly is meant by the term "moral human being" in Character Education. This is because whatever approach is used has to be based on the exact and clear understanding of the moral human being himself. A moral human being should posses the components categorised as concept, that is, the rules and principles which are deemed necessary to be used in actions and feelings or emotions which support the belief that a concept or action should be carried out. Apart from that, a moral human being should have the moral knowledge of the surroundings, know how to interact and act according to the decisions made. Character education will enable one to be a moral human being who should know the good, desire the good and do good.
\end{abstract}

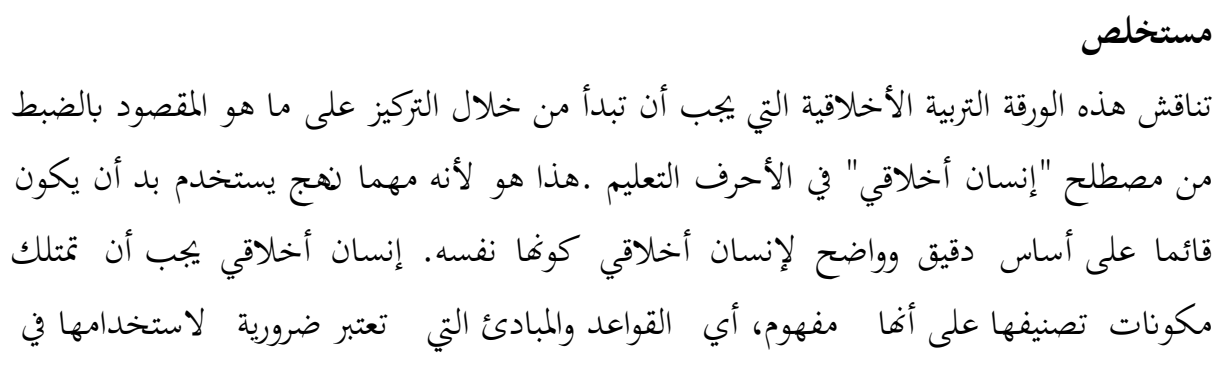

\footnotetext{
${ }^{1}$ Ed.D and Lecturer at School of Education and Modern Languages, Universiti Utara Malaysia

${ }^{2} \mathrm{Ph}$. D and Lecturer at School of Education, Universiti Sains Malaysia
} 
Vol. 3, No. 1, January 2015

$$
\begin{aligned}
& \text { الإجراءات والمشاعر أو العواطف التي تدعم الاعتقاد بأن مفهوم أو العمل ينبغي الاضطلاع بها . } \\
& \text { بغض النظر عن ذلك، ينبغي أن يكون إنسانا أخلاقيا المعرفة الأخلاقية للمحيط، ومعرفة كيفية } \\
& \text { لتفاعل والتصرف وفقا للقرارات. سوف التعليم الطابع تمكن واحد ليكون إنسانا أخلاقيا الذين } \\
& \text { يجب أن يعرفوا الخير، رغبة في الخير وفعل الخير. }
\end{aligned}
$$

Keywords: Moral, Education, Teacher, Character Education

\section{A. Introduction}

Character education is an umbrella term for all explicit and implicit educational activities that help young people develop positive personal strengths called virtues. Character education is more than just a subject. It has a place in the culture and functions of families, classrooms, schools and other institutions. Character education is about helping students grasp what is ethically important in situations and how to act for the right reasons, so that they become more autonomous and reflective.

Character education is one of the essential aspects in an individual from birth to death. It involves training human sensitivity to attitudes and behaviour, decisions and approaches to all types of knowledge which are dominated by ethical and spiritual values. He will be trained and disciplined mentally in the search for knowledge not merely to fulfill intellectual desire or material gains, but also to expand him self as a rational and righteous being contributing to physical prosperity, morality and spirituality of a family, society and humanity.

\section{B. The Aim of Moral Education}

Morality functions as the guideline in resolving conflicts among individuals and maximises the benefits of individuals living in the same community (Rest, 1986). Morality is centralised on the Kohlberg traditional concept of entailing fairness and respect towards the rights of others, emphasising justice and sympathy. Besides aiming to protect human 
dignity, rules enable humans to save energy and time to think of their behaviour. Nonetheless, a moral human being accepts values and society norms that are universally accepted as moral, good and true.

Hence, an individual with morals has to be aware and understand the needs of regulations in society (Abdul Rahman Aroff, 1986). A person with morals has to have noble characteristics that are praiseworthy morally. A person with a noble personality is one with a stable aptitude and personality in responding to a situation morally, manifested with kindness, honesty, responsibility and respect for others (Lickona, 1991a). More importantly, it contains ways of how a moral person should abide by the rules of the society and react effectively without conforming or complying with the rules blindly.

Hence, the preparation of such concepts of societal regulations and noble personality only are not sufficient to enable an individual to face moral dilemmas or complicated conflict values. An individual with morals should have principles and be autonomous in making decisions which are rational and truthful without any coercion or blind obedience to an authority. As such, ethics based on principles of justice and concerns are required.

Principles of justice are necessary to act in autonomous and rational ways in any situation in order to avoid selfishness and greed, and be able to control extreme behaviour in states of extreme anger. Moreover, humans cannot communicate with others if they do not understand one another. We will not be able to tolerate others who have different opinions, unless we have mutual understanding, congeniality and other methods to allow a win-win situation. Realising the fact that humans cannot live alone without the involvement of others, concern has become one of the important moral principles to avoid selfishness. It is considered as the principal value in generating other moral values especially the altruistic value (Abdul Rahman Aroff, 1999).

Therefore, ethics based on principles of justice and awareness has to be inculcated in an individual with morals besides taking into 
Vol. 3, No. 1, January 2015

consideration the situation faced. In order to complete the concept of ethics in a moral human being, it becomes a necessity to touch on the dimension or the aspect of an individual's tendency to behave morally. There are at least three ethical dimensions: moral reasoning, moral feelings and moral behaviour (Abdul Rahman Aroff,1999). An individual with morals should perform everything based on proper reasons. An individual who acts on a routine basis or fear or acts without thinking of the circumstances is not considered as a person with moral maturity or is doing things immorally. For instance, if we are training our children to avoid being racists without knowing the reasons, we are actually nurturing them immorally.

Only an individual who is doing the right action with convincing reasons is considered as a moral person. The concept of moral reasoning is necessary especially in this multiracial country in which the society has different significance and conformity of their core values. Reasoning is necessary to create justice in actions. In sum, moral reasoning will involve rationale and independence of thoughts, and consideration is the ability to consider and make mature moral decisions freely without being influenced by coercion or blind obedience.

Moral behaviour, on the other hand, is related to an individual's action and behaviour as a result of a decision made with full responsibility by independent and rational reasoning. An individual who does something which is considered inappropriate, unfair and immoral is considered as a person with low morals or one who is "knowledgeable but is not practising the knowledge". This phenomenon happens to an educated individual who is able to rationalise, yet is still doing illegal or immoral activities. An individual with morals will be altruistic, considerate, sympathetic, and generous as well as possess the traits of being concerned. Apart from that, the individual should be ashamed or feel guilty of doing something immoral. Nonetheless, a moral individual should not act emotionally as it will lead to irrational actions. Meanwhile, an individual with very low moral feelings is seen as being less human or impersonal. 


\section{Concept of Moral Education}

There are major principles recognised as the guideline in engendering human holistically, physically, intellectually, emotionally, spiritually and socially as aspired by the National Education Philosophy: "towards further development of individual potential holistically in tandem with producing a harmonious human being balanced intellectually, spiritually, emotionally and physically based on faith and obedience to God". The principles are:

a) Being responsible towards self, family and others.

b) Upholding religious belief.

c) Caring towards the environment.

d) Maintaining peace and harmony in life.

e) Being patriotic.

f) Respecting human rights.

g) Applying principles of democracy in life.

Diagram 1: Application of Values in Moral Appreciation

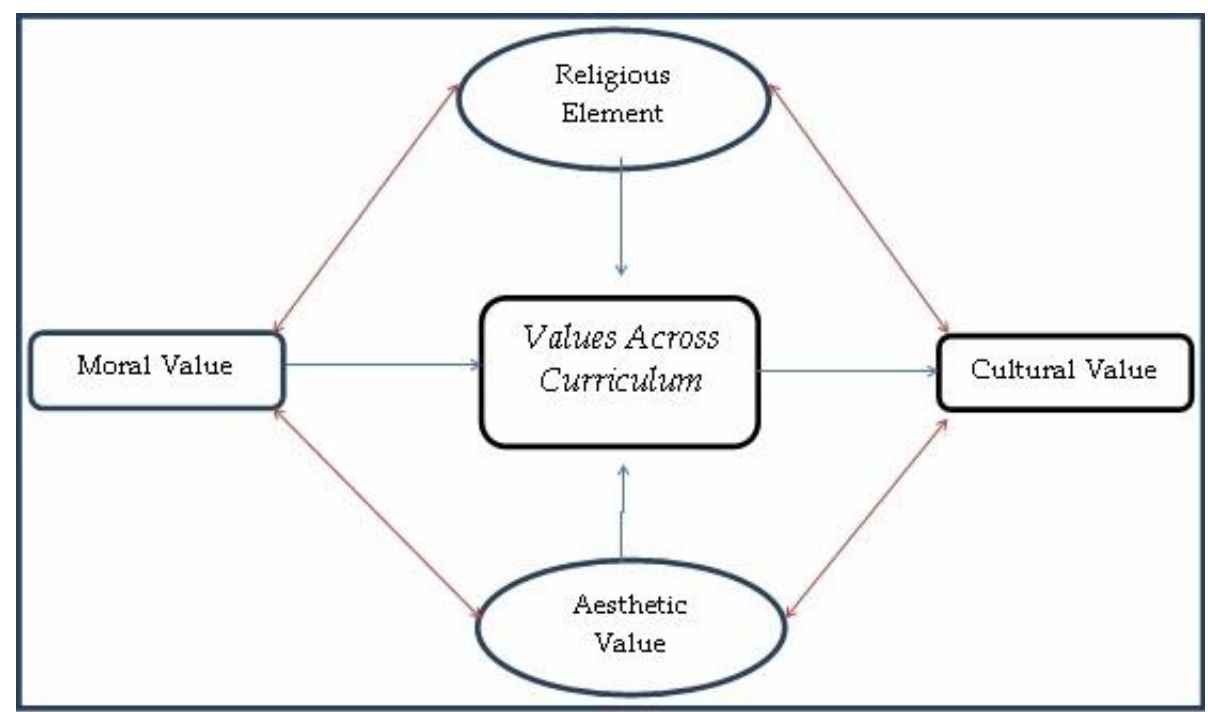

Diagram 1 shows that the absorption of values in learning across the curriculum is encouraged in strengthening students' behaviour regardless of their level of education. There are four 
Vol. 3, No. 1, January 2015

elements in the absorption of values across the curriculum - religious values, moral values, cultural values and aesthetic values. The implementation of religious values across the curriculum is made up of ethics, humanity and religion. This is done so that religious belief could be upheld and appreciated in accordance with the atmosphere and complexity of the human life in carrying out daily activities.

For instance, being thrifty is encouraged in Islam. Hence, spending wisely can be applied and practised by students in their daily lives, similar to the practice in workshops.

The application of religious values in the learning sessions will enhance the students' personal character. The next element is the absorption of moral values in the curriculum which comprise of spiritual and communal ways of living. One of the examples is cooperating with the locals to clean public areas; thus inculcating the neighbourhood spirit indirectly. This could be implemented in the learning sessions by having group activities in associations, clubs and uniformed units. Meanwhile, cultural values comprise ways of life, social and tradition. These values embrace the variety of values possessed bya group of people in a community such as the culture of respecting the elders, and courtesy.

Finally, other values that should be implemented across the curriculum are the values of arts, beauty and feelings. It includes pleasure, satisfaction and excitement in human life especially in the arts and culture. Arts can be seen from the production of architecture, drawings, visual arts and others.

\section{Direction/ Future of Moral Education in Character Education}

Character education is the process of an individual or society internalising culture leading to civilisation. Character education is not only a means of knowledge transfer, but broader in which it encompasses cultural and nurture of values. A child should get an education that touches on the humanity dimension. The humanity dimension includes at least three most basic points: 
(1) Affective which is reflected in the quality of faith, piety and moral behaviour inclusive of the noble character, dominant personality, and ethical competency;

(2) Cognitive which is reflected in the thinking capacity, and intellect to seek, expand and master knowledge and technology;

(3) Psychomotor which is reflected in the ability to expand skills, practise efficiency and kinetic competency.

Character education in the moral education programme focuses on the Comprehensive Human Model which comprises of three interrelated moral dimensions. (Diagram 2: Comprehensive Human Model). The positive character should consist of these three moral dimension s- moral thoughts, moral emotions and moral action. An effective moral education should assist the students to understand the moral values, accept and show commitment, and practise them in their daily lives. These three dimensions are necessary to enable a student to reach moral maturity level. The best moral development theory is one that considers all the three dimensions. The development of the three moral dimensions will nurture and stimulate conscience causing an individual to feel happy doing the right thing and feel guilty doing something immoral. Moral education should not neglect the aspect of conscience that functions to integrate the three moral dimensions.

Meanwhile Walker et al. (2000) describes the moral domain as consisting of moral emotion, moral behaviour, moral thought, commitment and noble behaviour. The discussion above indicates that certain qualities, character or skills for a moral individual should be identified in designing and planning the moral education process as a whole. In conjunction with this, Abdul Rahman Aroff (1999) proposed the concept of ethics and the moral human being which is considered suitable especially in the context of a multiracial society in Malaysia. Ethics is conceptualised from three perspectives: content, design and dimension. Morality or ethics should have content that consists of the 
Vol. 3, No. 1, January 2015

regulations of the society and noble characteristics. Each group in a society has its own regulations in order to ensure people could live and function well with its environment.

Thus, morality cannot expunge itself from regulations, norms, traditions or customs in society. Due to this, as explained by John Wilson (1973), societal regulations and noble character should be understood by each individual as moral thoughts do not evolve in vacuum. Human social life cannot go on without regulations as they are yardsticks to evaluate any social activity (Wright, 1971).

The concept of moral education will be introduced and enhanced through "inter-disciplinary" minor courses to balance the understanding of the comprehensive education concept in Malaysia. This is to prove that humans are the successors in the physical, social, emotional and spiritual aspects which embrace human needs as a whole.

The aspects that are stressed in the Moral Education programme are based on three main aims:

\section{Knowledge}

a. Recognise values that can contribute towards the development of moral values such as sincerity, respect, personal responsibility, perseverance and moral courage.

b. Explain family traditions and be familiar with qualities which unite a family such as love, attention, being respectful, and commitment as well as preserving the family name.

c. Explain the principles of cooperation which can make each occupation in the community a success.

d. Realise the country's accomplishment and identify the appropriate behaviour of a responsible citizen.

\section{Skills}

a. Apply moral reasoning skills and creative thinking in making decisions, solving problems and moral dilemma, defining problems, evaluating suitable choices and deciding on an action. 
b. Share and understand the feelings of others.

c. Cooperate and unite in managing an action.

d. Utilise talents and abilities to do social work.

\section{Attitude}

a. Ability to control moral strength and personal responsibility.

b. Show courage and diligence in facing difficulties and be prepared to act.

c. Respect the feelings of others on ethnicity, race and culture.

d. Show willingness to serve for the wellbeing of the community and society.

e. Exhibit a sense of belonging and love towards Malaysia.

Apart from that, character development also focuses on the soft skills concept. The definition should always refer to the concept of integrated education and values explained above. In detail, the soft skills concept has to be developed with the integration of seven (7) components ethics and moral, leadership, communication, entrepreneurship, thinking skills, continuous learning and information management, and teamwork. Character development is accomplished by means of the global thinking approach; however it acts nationally, that is, in accordance with Malaysia's identity. With this strategy it is hoped that Malaysia produces world scholars or intellectuals.

\section{E. Moral Education Teachers' Challenges in Enhancing Character Education}

Educators entrusted to teach moral education should have the basic knowledge and skills especially with regard to inner needs and approaches. This is because moral education is complex and has caused a lot of confusion in character education. Teaching moral education is not the sole responsibility of the Moral Education teacher in the school, but it also requires the cooperation of everyone including parents and the school especially in promoting a moral environment. According to Puka (2002), if an educator does not know what morality 
Vol. 3, No. 1, January 2015

is he is not qualified to teach (Abdul Rahman Aroff, 1986). Hence, the preparation of a moral education teacher should be taken seriously because in reality, moral education is not what it is assumed to be. The moral concept held by educators will influence the aim, content and especially the methods of teaching moral education. For example, an educator who understands moral education as absolute compliance to the rules will act as an authoritarian and the moral education programme will be indoctrinated; the implication of which will hinder the process of mature moral development.

Besides, the Malaysian Education Development plan of 2013-2025 has been adjusted with the conceptual curriculum framework focusing on nurturing the Comprehensive Human Model in all three moral dimensions moral thinking, moral emotion and moral behaviour. In terms of moral psychology, the development of character in the three moral dimensions thinking, emotion and behaviour - are the essentials in the perception framework. Moral philosophy offers us the causes and the definition of assumptions and ideas of good deeds, and should be practised by individuals in their relationship with others. However, moral psychology expands our understanding of behaviour and the development of human capacity (cognitively and affectively) in making moral judgements and acting as a responsible moral agent (Chang Lee Hoon, 2001).

The second dimension emphasises the emotional aspect; moral feelings. Moral feelings refer to the "right feelings" and it involves rationalisation in the situation encountered (Ministry of Education Malaysia, 2001). Students should be able to express their feelings sympathy, empathy, disappointment, anger and so on and so forth - while explaining their views on moral issues. Moral behaviour, on the other hand, is the third dimension in the student learning concept framework. Students who have been given the opportunity to review an issue or moral situation should be given the chance to also propose solutions to resolve the matter. It is in this third dimension that students are able to show their commitment physically as a manifestation of the result of their thoughts and moral feelings. 
Quality teachers are positive teachers with clear directions, able to adapt to various situations, are creative, smart, motivated, passionate in teaching, competent and skilful in the subject, empathetic, and moral and so on and so forth. A teacher is considered to be a responsible moral agent in assisting students with values of love and close social relationships. This is because there are some students who grow up in a tumultuous and confused society especially in the aspect of moral development. If a teacher acts negatively, it will affect the students' moral development (Ab. Halim Tamuri, 2007). Nonetheless, the roles and responsibilities of character education do not rely solely on teachers, but families and society also play significant roles in nurturing the children's character informally. The diagram below shows the roles and responsibilities of character education.

Diagram 2: Roles and Responsibilities in Character Education

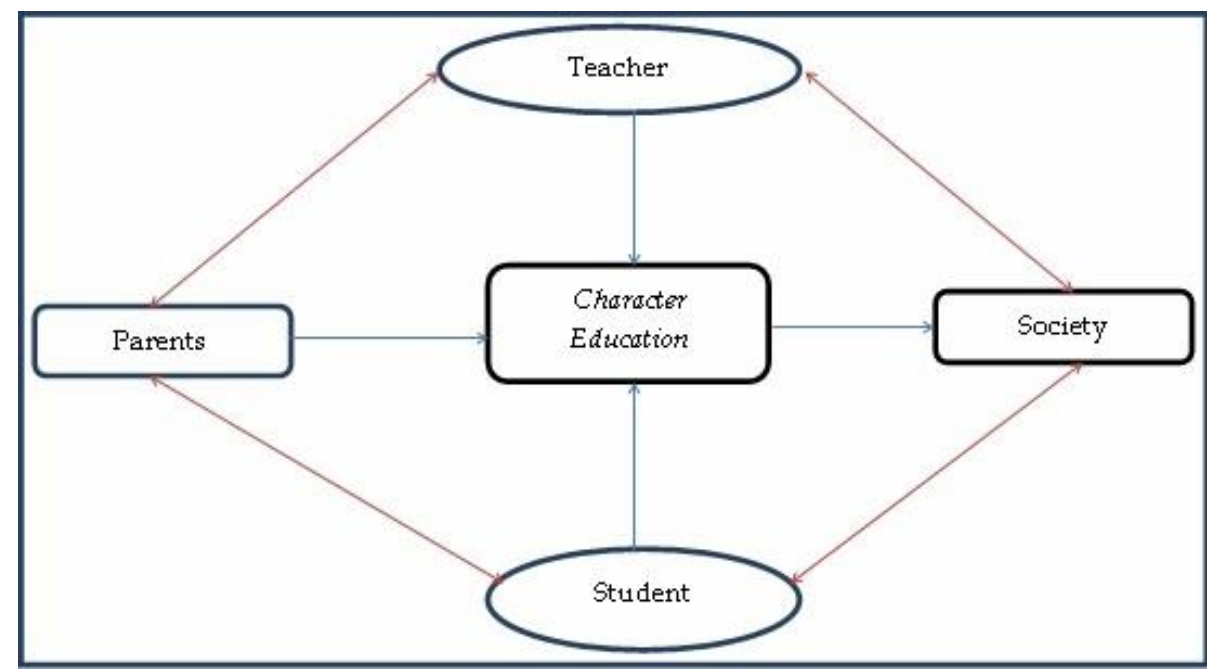

Apart from that, one of the government's vital agenda is to develop a world- class education system without leaving out the aspect of character education as a medium in character development. This system focuses on comprehensive human capital development, is progressive, and has high moral and ethics. Holistic human development requires physical, emotional, spiritual and intellectual balance and the ability to become trained and competitive nationally and internationally in line with the 2020Vision. 
Vol. 3, No. 1, January 2015

\section{F. Conclusion}

Morality is behaviour determined by ethics. Behaviour derived from good or bad ethics is labelled as morality. Morality is divided into two: good; which includes all behaviour which is recognised as ethically correct, and bad; which is recognised as ethically bad. Morality is related to societal regulations which exist beyond individual control. Dorothy Emmet (1979) stated that humans are dependent on good behaviour and morality, traditions, norms and religion in assisting in the evaluation of one's behaviour. Behaviour in Islam is closely related to a Muslim's faith.

Besides, the concept of moral education intends to nurture a quality human being who is able to perform his duties and responsibilities as a moral person. The process of moral education plays a significant role in educating human beings taking into account the fact that human beings were created in terms of mind, body and spirit. The concept will have a great impact on human life and make human beings the inheritors of earth.

\section{Bibliography}

Ab. Halim Tamuri. 2007. Islamic education teachers perceptions of the teaching of akhlaq in Malaysian secondary schools. Journal of Moral Education. 36: 371-386.

Abdul Rahman Md Aroff. 1986. Makna Moral. Jurnal Kementerian Pendidikan Malaysia (68).

Abdul Rahman Md Aroff. 1999. Pendidikan moral: Teori etika dan amalan moral. Serdang: Penerbit Universiti Putra Malaysia.

Chang Lee Hoon. 2001. Learning to teach moral education. Paper presented at Association of Moral Education Conference: Excellence in Moral Education.Vancouver, November 24-27, 2001.

Chang, Lee Hoon. 2002. Perkembangan domain moral dalam pengajaran dan pembelajaran sains sosial. Kertas pembentangan 
Seminar kebangsaan Pengajaran dan Pembelajaran Sains Sosial. Fakulti Pendidikan, Universiti Malaya pada 19 Januari 2002.

Chang, Lee Hoon. 2004. Emosi moral dalam Pendidikan Moral.Seminar Pendidikan Akhlak \& Moral Pembinaan Insan, 23-24 Juli 2004, Kuala Lumpur, Malaysia.

Emmet, D. 1979. The moral prism. Macmillan: London.

Gilligan, C. 1982. In a different voice: Psychological theory and women's development. Cambridge, MA: Harvard University Press.

Kementerian Pendidikan Malaysia. (2001). Sukatan pelajaran pendidikan moral. Kuala Lumpur: Pusat Perkembangan Kurikulum.

Narvaez, D., Getz, I., Rest, J.R., \& Thoma, S.J. 1999. Individual moral judgment and cultural ideologies. Developmental Psychology, 35, 478-488.

Ewing, C.P. 1990. When children ill. The Dynamics of Juvenile Homicide.

Lickona,T. 1991. Educating for character: How our schools can teach respect and responsibility. New York: Bantam.

Noddings, N. 1984. Caring: A feminine approach to ethics and moral education.Berkeley, CA:University of California Press.

Puka, B. (2002). The DIT and the dark side of development. Journal of Moral Education, 31, (3), 339-352.

Rest, J.R. 1983. Morality. In J.H. Flavell \& E.M. Markman (Eds.). Cognitive development: Handbook of child psychology (vol. 3, pp. 556-629). New York: John Wiley \& Sons.

Samay, S.A. 1986. Affectivity : The power base of moral behaviour. In G.F. Mc Lean, F.E. Ellrod, D.L. Shindler \& J. Character Development. New York : University Press of America.

Walker, L. J. 1999. The perceived personality of moral exemplars. Journal of Moral Education, 28, 145-162.

Walker, L. J. 2004. Gus in the gap: Bridging the judgment action gap in moral functioning. In D. K. Lapsley \& D. Narvaez (Eds.), Moral development, self, and identity (pp. 1-20). Mahwah, NJ: Lawrence Erlbaum. 
Vol. 3, No. 1, January 2015

Walker, L. J., Hennig, K. H., \& Krettenauer, T. 2000. Parent and peer contexts for children's moral reasoning. Child Development, 71, 1033-1048.

Wilson, John. 1973. A teacher's guide to moral education. London: Geoffrey Chapman.

Wright, Derek. 1971. The psychology of moral behaviour. Hazell Watson \& Viney Ltd.

$* * * * *$ 